\title{
Economic and soil quality indicators in soybean crops grown under integrated crop-livestock and winter-grain cultivation systems
}

\author{
Relação entre indicadores econômicos e edáficos de qualidade do solo em lavouras \\ de soja com ILP ou produção de grãos no inverno \\ Flávio José Simioni ${ }^{I}$ Marie Luise Carolina Bartz ${ }^{I I}$ Leandro do Prado Wildner ${ }^{I I I}$

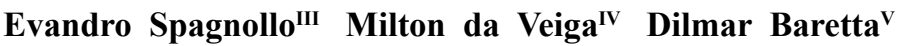

\section{ABSTRACT}

This study aimed to evaluate the relationship between economic indicators of soybean crops (Glycine max L.) cultivated with Crop-Livestock Integration (CLI) or with grain production in winter, and the chemical, physical and biological attributes of the soil. It was selected ten agricultural sites in Santa Catarina to measure economic results and edaphic attributes, data was submitted to a Principal Components Analysis (PCA). Results indicated that soybean production in the summer and grain production in the winter yielded better economic results compared with summer soybean and CLI in winter. This reflects the higher productivity of the crops (9.1\%) and the improved chemical, physical, and biological attributes of the soil (with the exception of organic matter content and macroporosity, which were better under the soybean system with CLI).

Key words: crop-livestock integration, cost of production, multivariate analysis.

\section{RESUMO}

O estudo teve como objetivo avaliar a relação entre resultados econômicos de lavouras de soja (Glycine max L.) cultivadas com Integração Lavoura-Pecuária (ILP) ou produção de grãos no inverno e atributos químicos, físicos e biológicos do solo. Foram selecionadas dez propriedades rurais, consideradas referência em Santa Catarina, para a determinação dos resultados econômicos das lavouras de soja e dos atributos edáficos, que foram submetidos à análise de componentes principais (ACP). Os resultados indicam que o sistema de produção de soja no verão e grãos no inverno apresentou melhores resultados econômicos em comparação com o sistema de soja no verão e ILP no inverno. Este resultado decorre da maior produtividade das lavouras (9,1\%), devido às melhores condições químicas, físicas e biológicas do solo, com exceção do teor de matéria orgânica e da macroporosidade, que ficaram mais associadas ao sistema soja com ILP.

Palavras-chave: integração lavoura-pecuária, custo de produção, análise multivariada.

\section{INTRODUCTION}

The production of soybean in Santa Catarina has grown significantly in the last five years as a result of an increase implanted area $(9.8 \%)$ and productivity gains (14.9\%). As a consequence, the deficit of 166 thousand tons in 2007-2008 was transformed into a surplus of 409.3 thousand tons in 2013-2014 (EPAGRI, 2014a).

Soybean cultivation during the harvest period in the state is conducted predominantly under a no-till system (NTS) in rotation with winter grain crops (second crop), or in remnants of pasture used for fattening cattle for beef or milk production, a pattern characteristic of Crop-Livestock Integration

IPrograma de Pós-graduação em Ciências Ambientais, Centro de Ciências Agroveterinárias (CAV), Universidade do Estado de Santa Cataria (UDESC), 88520-000, Lages, SC, Brasil. E-mail: flavio.simioni@udesc.br. Corresponding author.

IIPrograma de Pós-graduação em Gestão Ambiental, Universidade Positivo (UP), Curitiba, PR, Brasil.

III Centro de Pesquisa para Agricultura Familiar (CEPAF), Empresa de Pesquisa Agropecuária e Extensão Rural de Santa Catarina (EPAGRI), Chapecó, SC, Brasil.

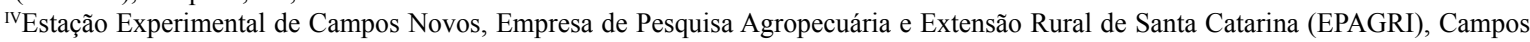
Novos, SC, Brasil.

'Programa de Pós-graduação em Zootecnia, Centro de Educação Superior do Oeste (CEO), Universidade do Estado de Santa Cataria (UDESC), Chapecó, SC, Brasil. 
(CLI) (BARETTA et al., 2014). Studies showed that NTS and CLI both have agronomic advantages and improve edaphic attributes, especially the biodiversity of earthworms in Santa Catarina (BARTZ et al., 2011; BARETTA et al., 2014).

Economic results produced by these two cultivation systems; however, are subjected to a dispute. According to MARTHA JUNIOR et al. (2011), CLI (soybeans with beef cattle, with $50 \%$ of the area occupied with livestock and the remainder with soybean) is competitive with specialized systems for livestock farming, but presents no competitive advantage in comparison to specialized soybean systems due to the greater need for capital. For LAZZAROTTO et al. (2010), the integration of crops with beef cattle, compared to specialized systems with only grain or with livestock for slaughter, is recommended as the best alternative. SILVA et al. (2012) also concluded that CLI that incorporated rearing dairy heifers in annual winter pastures, in preference to the cultivation of winter cereals and or soil cover crops, is the more profitable alternative for producers.

There is scarce information from Brazil, and especially from Santa Catarina, on the economic efficiency of soybean cultivation and CLI and their relation to soil attributes. So, the present study was conducted to assess the relationship between the economic results from soybean cropping with CLI or with grain production in winter and the chemical, physical, and biological attributes of the soil.

\section{MATERIALS AND METHODS}

The study was conducted in ten rural reference properties in Santa Catarina, each with more than five years under no-tillage and CLI management, located in the municipalities of Abelardo Luz (1), Campos Novos (1), Chapecó (1), Curitibanos (1), Guaraciaba (1), Guatambu (3), Maravilha (1) and Pinhalzinho (1). The sites were considered true replicates with respect to the studied systems (PEREIRA et al., 2013; BARTZ et al., 2014a).

Technical and economic data on soybean crops grown in the 2012-2013 crop year were obtained, and the nominal prices in May 2013 were used as a reference. A structured spreadsheet was used to calculate the production costs and economic results, in accordance to the methodologies used by the Empresa de Pesquisa e Extensão Rural de Santa Catarina (EPAGRI, 2014b) and by the Companhia
Nacional de Abastecimento (CONAB, 2010). Soil samples were collected in November 2012 and February 2013 to assess their chemical, physical, and biological attributes.

Sites were grouped into two use and management systems for multivariate analysis, making up the treatments Soybean+Grain, i.e. soybean cultivation in summer (harvest) and grain production in winter (second crop) $(n=5)$, and Soybean+CLI, i.e. soybean cultivation in summer (harvest) and CropLivestock Integration in winter, when the area was used for cultivation of oat and ryegrass for grazing cattle $(n=5)$.

The economic variables used as response variables in the analyses, following HOFFMANN et al. (1987) and SOLDATELLI et al. (1992), were: (a) Gross Revenues (GR), considered as the quantity produced valued according to the market price of May 2013; (b) Gross Margin (GM), value remuneration of fixed costs; (c) Net Revenues (NR), value remuneration of opportunity costs (capital and venture); (d) Profit (PROFIT), final result after the remuneration of all production factors; (e) Break-even Point (BP), production required to cover the total cost; (f) Rate of Land Remuneration (RLR), remuneration which accrued to the land after compensation for all other production factors; and (g) Total Factor Productivity (TFP), measure of efficiency, i.e. number of monetary units received for each monetary unit expended.

In each selected area soil samples were collected at three equally spaced points $(30 \mathrm{~m}$ apart), and chemical, physical, and biological attributes of the samples were determined. The unstructured samples collected for chemical analysis were taken from the $0-10 \mathrm{~cm}$ layer and were evaluated for $\mathrm{pH}$ in water $(\mathrm{pH})$, organic matter $(\mathrm{OM})$, extractable phosphorus $(\mathrm{P})$, exchangeable potassium $(\mathrm{K})$, aluminum $(\mathrm{Al})$, calcium $(\mathrm{Ca})$, and magnesium $(\mathrm{Mg})$, according to the methodology described by TEDESCO et al. (1995). Structured soil samples were collected with volumetric rings in the $2-7 \mathrm{~cm}$ layer at the same locations as the samples for chemical analysis, and the following physical attributes of these samples were measured, according to VEIGA (2011): soil bulk density (BD); resistance to penetration (RP); total pore volume (PV); macropore volume, i.e. pores with a diameter $>50$ micrometers (MacroP); micropore volume, i.e. pores with a diameter $<50$ micrometers (MicroP); and the geometric mean diameter of the air-dried aggregates (GDM). Biological attributes quantified were total 
abundance, total biomass and earthworm species richness, as suggested by BARTZ et al. (2013). It was also used as an explanatory variable the use (1) or non-use (0) of organic fertilizer (ORGF) in the sampled areas.

The response and explanatory variables of the groups Soybean+Grain and Soybean+CLI were submitted to analysis of variance, using a completely randomized design, and the means were compared by Student's t-test $(\mathrm{P}=0.05)$. To address the proposed objectives, the data were also submitted to multivariate analysis. Thus, the economic results used in the analysis as the response variables were used to obtain the length of the gradient (DCA) and, as this was less than three (linear response), it was chosen Principal Components Analysis (PCA) and used the CANOCO program version 4.5 (TER BRAAK \& SMILAUER, 1998; BARETTA et al., 2014).

Initially, all response variables analyzed were considered in the PCA (Figure 1A). Subsequently, considering the weight that the analysis assigned to each component, only the most significant response variables were used, excluding the other variables (Figure 1B), in order to obtain greater robustness and reliability in the analysis, as suggested by BARETTA et al. (2014). Finally, the significant physical, chemical and biological soil attributes were added a posteriori to assess the changes in economic results.

\section{RESULTS AND DISCUSSION}

In the univariate analyses, no significant differences were observed between Soybean+Grain and Soybean + CLI in production costs, economic results, or in any of physical and chemical soil attributes (Tables 1 and 2). This absence of significant differences was due to large measure of analytical results presenting very heterogeneous values for most parameters and so raising the coefficient of variation, as a result of differences in the historic of area use, technological level adopted and reduced sample size of properties.

An absence of differences between some physical soil attributes has been reported previously by SPERA et al. (2009). This may have occurred due to the fact that samples were collected after the
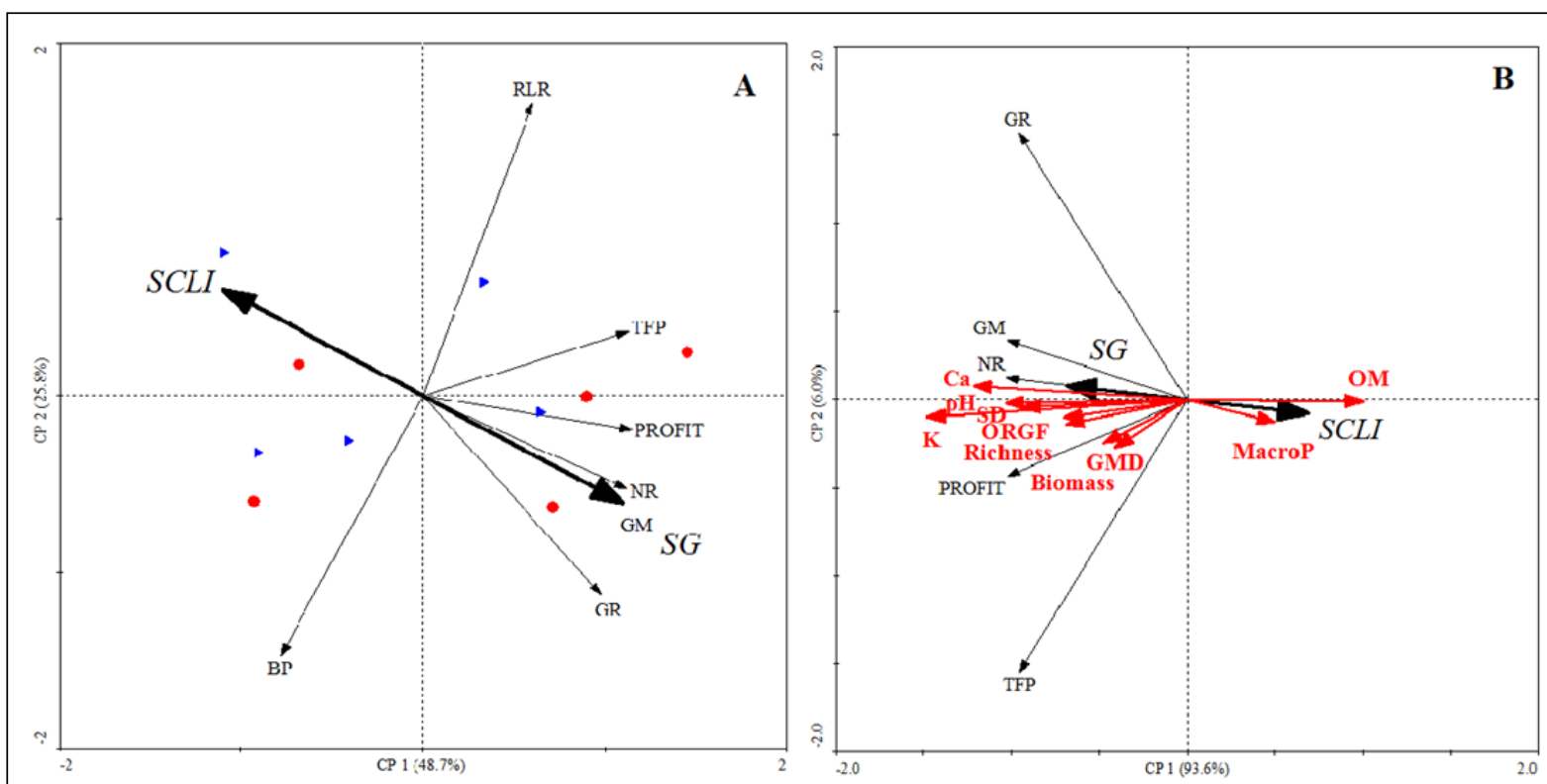

Figure 1 - Relation between the principal components $1(\mathrm{CP} 1)$ and $2(\mathrm{CP} 2)$ for the treatments Soybean+Grain (SG) and Soybean+CLI (SCLI) with (A) all response variables (GR, Gross Revenue; GM, Gross Margin; NR, Net Revenue; PROFIT, Pure Profit; BP, Break-even Point; RLR, Rate of Land Remuneration; TFP, Total Factor Productivity); and with (B) selected response variables (GR, GM, NR, PROFIT, and TFP) and with selected explanatory variables added a posteriori ( $\mathrm{pH}, \mathrm{pH}$ in water; Ca, Calcium; K, Potassium, OM, Organic Matter; SD, Soil Density; MacroP, Volume of Macropores; GMD, Geometric Mean Diameter of the air dried aggregates; ORGF, Organic Fertilization; Richness, number of species of earthworms; Biomass, average weight of earthworms). 
Table 1 - Average values and coefficients of variation (\%) of the production costs and economic resultsof soybean production in Soybean + Grain systems and Soybean+CLI systems used as response variables.

\begin{tabular}{|c|c|c|c|}
\hline \multirow{2}{*}{ Specification } & \multirow{2}{*}{ Unit } & \multicolumn{2}{|c|}{--Cultivation System--- } \\
\hline & & Soybean+Grain $(5)$ & Soybean+CLI $(5)$ \\
\hline Total Variable Cost (TVC) & $\mathrm{R} \$ \mathrm{ha}^{-1}$ & $1056.52(22.8)$ & $1147.92(5.2)$ \\
\hline Total Fixed Cost (TFC) & $\mathrm{R} \$ \mathrm{ha}^{-1}$ & $517.18(19.6)$ & $436.15(22.0)$ \\
\hline Total Operational Cost (TOC) & $\mathrm{R} \$ \mathrm{ha}^{-1}$ & $1240.28(20.0)$ & $1302.49(5.9)$ \\
\hline Total Cost (TC) & $\mathrm{R} \$ \mathrm{ha}^{-1}$ & $1573.69(18.1)$ & $1584.07(8.9)$ \\
\hline Gross Revenue (GR) & $\mathrm{R} \$ \mathrm{ha}^{-1}$ & $3348.03(10.6)$ & $3056.5610 .4)$ \\
\hline Gross Margin (GM) & $\mathrm{R} \$ \mathrm{ha}^{-1}$ & $2291.52(22.6)$ & $1908.64(17.7)$ \\
\hline Net Revenue (NR) & $\mathrm{R} \$ \mathrm{ha}^{-1}$ & $2107.75(23.2)$ & $1754.07(20.9)$ \\
\hline Pure Profit (PROFIT) & $\mathrm{R} \$ \mathrm{ha}^{-1}$ & $1774.34(27.7)$ & $1.472 .49(25.2)$ \\
\hline Break-evenPoint (BP) & sc ha ${ }^{-1}$ & $30.11(17.3)$ & $30.46(8.9)$ \\
\hline Rate of LandRemuneration (RLR) & $\%$ & $5.75 \%(34.6)$ & $7.09 \%(49.1)$ \\
\hline Total Factor Productivity (TFP) & un & $2.19(22.4)$ & $1.94(15.1)$ \\
\hline
\end{tabular}

Notes: (1) Nominal values for May 2013.(2)For all variables there was no difference between the averages by a t-test at the 5\% significance level.

summer crop harvested, approximately six months after the removal of the animals from the area. According to VEIGA et al. (2012), cattle trampling promotes compression of the superficial soil layer $(0-10 \mathrm{~cm})$, but this reverses during the cropping cycle following pasturage, when the wetting and drying cycles of the soil and the decomposition of the root systems resulted in a reduction in internal soil pressure.

Nevertheless, although there were no significant differences for the variables analyzed, it was observed superior economic results from the Soybean+Grain as opposed to the Soybean+CLI system, essentially due to the higher productivity (9.1\%) obtained in these areas $\left(3848.16 \mathrm{~kg} \mathrm{ha}^{-1}\right.$ against $3526.80 \mathrm{~kg} \mathrm{ha}^{-1}$ ), thus generating higher gross revenues (Table 1). Higher productivity in Soybean+Grain areas resulted from the better chemical, physical, and biological characteristics of the soil. Studies revealed that the adoption of well-managed NTS provides better physical, chemical, and biological conditions to the soil, and consequently a more favorable environment for growth and plant productivity due to the absence of physical obstructions to the absorption of nutrients (SPERA et al., 2009).

The difference in soybean yield between the two systems could be explained, in part, by the quantity of phytomass in the remaining pasture, which decreases with increasing cattle grazing intensity (VEIGA et al., 2012). The lower quantity of phytomass resulted in lower soil coverage and, consequently, in increasing in soil temperature and water evaporation, reducing the availability of water for the following crop, mainly at the beginning of its cycle (VEIGA et al., 2010). All attributes analyzed by PCA showed, again, that Soybean+Grain system stood out, displaying a higher association with all the economic indicators assessed (Figure 1A). This can be explained not only by the abovementioned factors but also because this system presents higher values of $\mathrm{pH}, \mathrm{Ca}, \mathrm{K}, \mathrm{DS}, \mathrm{DMG}$, ORGF, Richness, and Biomass (Figure 1B). Only organic matter content and macro porosity were more strongly associated with Soybean+CLI, indicating that these attributes are the most sensitive main indicators of changes in soil arising from use and management systems.

The increase in macroporosity stems from the decrease in soil density and in compression under CLI (Figure 1B) (CORSINI \& FERRAUDO, 1999; MARCHÃO et al., 2007; SILVA et al., 2011). Furthermore, macroporosity is an important physical attribute in the analysis of pores distribution in the soil, especially because it is linked to hydraulic conductivity. In this study, it is also correlated with an increase in organic matter, in addition to the greater capacity of porosity occupied with the air in the soil and related with the highest rate of diffusion of oxygen in the soil of CLI (GREENLAND, 1981). 
Table 2 - Average values and coefficients of variation (\%) of the chemical, physical, and biological soil attributes of areas cultivated with Soybean+Grain and Soybean+CLI, used as explanatory variables.

\begin{tabular}{|c|c|c|c|}
\hline \multirow{2}{*}{ Explanatory Variables } & \multirow{2}{*}{ Unit } & \multirow{2}{*}{ Soybean + Grain $(5)$} & \multirow[b]{2}{*}{ Soybean+CLI(5) } \\
\hline & & & \\
\hline Organic Fertilization (ORGF) & $\mathrm{No}=0 \mathrm{Yes}=1$ & $0.80(55.9)$ & $0.40(136.9)$ \\
\hline $\mathrm{pH}$ (water) & un & $5.52(11.8)$ & $5.74(10.7)$ \\
\hline Phosphorus & $\mathrm{mg} \mathrm{dm}{ }^{-3}$ & $16.84(73.8)$ & $15.36(109.3)$ \\
\hline Potassium & $\mathrm{mg} \mathrm{dm}^{-3}$ & $267.78(29.8)$ & $273.86(31.9)$ \\
\hline Organic Matter & $\%$ & $4.28(28.9)$ & $4.06(14.7)$ \\
\hline Aluminum & $\mathrm{cmol}_{\mathrm{c}} \mathrm{dm}^{-3}$ & $0.36(196,9)$ & $0.40(75.1)$ \\
\hline Calcium & $\mathrm{cmol}_{\mathrm{c}} \mathrm{dm}^{-3}$ & $5.60(31.8)$ & $6.52(21.4)$ \\
\hline Magnesium & $\mathrm{cmol}_{\mathrm{c}} \mathrm{dm}^{-3}$ & $2.80(43.2)$ & $2.61(36.2)$ \\
\hline Soil Density & $\mathrm{gcm}^{-3}$ & $1.27(16.4)$ & $1.21(6.2)$ \\
\hline Resistance to Penetration & $\mathrm{kgf} \mathrm{cm}^{-2}$ & $3.05(18.1)$ & $2.19(24.3)$ \\
\hline Total Porosity & $\mathrm{cm}^{3} \mathrm{~cm}^{-3}$ & $0.53(5.8)$ & $0.56(6.6)$ \\
\hline Macroporosity & $\mathrm{cm}^{3} \mathrm{~cm}^{-3}$ & $0.12(20.3)$ & $0.13(15.5)$ \\
\hline Microporosity & $\mathrm{cm}^{3} \mathrm{~cm}^{-3}$ & $0.38(4.3)$ & $0.40(8.9)$ \\
\hline Geometric Mean Diameter & $\mathrm{mm}$ & $2.20(16.4)$ & $2.16(22.2)$ \\
\hline Total Abundance & ind $\mathrm{m}^{-2}$ & $28.80(163.7)$ & $32.00(194.0)$ \\
\hline Total Biomass & $\mathrm{g} \mathrm{m}^{-2}$ & $3.16(187.3)$ & $5.34(172.7)$ \\
\hline Average Species Richness & number of species & $0.40(108.7)$ & $1.20(136.9)$ \\
\hline
\end{tabular}

Note: For all variables, there was no difference between the means by at-test at the $5 \%$ significance level.

This same pattern of higher levels of organic matter and macroporosity and lower diversity of edaphic fauna, especially of earthworms in Soybean+CLI systems, was also observed by several other authors in soils in the state of Santa Catarina (BARETTA et al., 2003; SILVA et al., 2011; BARETTA et al., 2014; BARTZ et al., 2014b). These authors attributed this pattern to the effective management of the animals in the Soybean+CLI system compared to Soybean+Grain, a pattern similar to what occurred in the present study. However, in the present study, it is important to take into consideration that the cattle were introduced for grazing only when the soil was relatively dry, thus avoiding grazing on soil with moisture favourable to compaction (SPERA et al., 2009).

Regarding the biological data (biomass and earthworm species richness) in the PCA, they were more associated with the Soybean+Grain areas. This association can be explained by the fact that the presence and abundance of earthworms is directly associated with soil management, and earthworms positively affected plant production by their action on the physical and chemical attributes of the soil (BROWN et al., 2007).

These results confirm numerous isolated soil science studies that analyzed only one or another edaphic attribute (BARETTA et al., 2003; SPERA et al., 2009; VEIGA et al., 2010, BARTZ et al., 2011; VEIGA et al., 2012; BARTZ et al., 2013; BARTZ et al., 2014b; BARETTA et al., 2014). The results of this study, however, presented in a new, holistic, and innovative manner, the relationships between the economic data and the physical, chemical and biological soil attributes, relationships not revealed by univariate analysis alone.

The experimental design used in the present study, with true replicates of soil-use systems and a robust multivariate analysis tool, was very effective in demonstrating the existing relations between economic results and soil attributes, allowing a more holistic view of the treatments effects. We recommend these procedures be adopted in other studies.

\section{CONCLUSION}

In general, one can conclude that the Soybean+Grain system yielded better economic results for soybean cultivation (GR, GM, NR, $\mathrm{P}, \mathrm{BP}, \mathrm{RLR}$, and TFP), mainly due to higher productivity as a result of better chemical $(\mathrm{pH}$ in water, $\mathrm{Ca}$, and $\mathrm{K}$ ), physical (SD, GMD, and 
ORGF) and biological (higher species richness and earthworm biomass) soil conditions.

Additional studies should be carried out in this area around this theme, because few have yet been performed in Southern Brazil. Also, there is a need to assess whether the gains in cattle production in the various farming systems compensate for the losses in soybean productivity when cultivated in CLI, and so provide economic advantages.

\section{ACKNOWLEDGEMENTS}

We acknowledge the financial support of this project (PA 897/11) by the Agrisus Foundation. And also a special thanks to the farmers that allowed us to do research in their farms, as well, to the graduate and undergraduate students and technicians of Universidade do Estado de Santa Catarina (UDESC), Centro de Educação Superior do Oeste (CEO) and EPAGRI a for technical assistance.

\section{REFERENCES}

BARETTA, D. et al. Fauna edáfica avaliada por armadilhas e catação manual afetada pelo manejo do solo na região oeste catarinense. Revista de Ciências Agroveterinárias, v.2, p.97-106, 2003. Available from: <http://www.revistas udesc.br/index.php/agroveterinaria/article/view/5616/3798> Accessed: Dec. 20, 2014

BARETTA, D. et al. Soil fauna and its relation with environmental variables in soil management systems. Revista Ciência Agronômica, v.45, p.871-879, 2014.Available from: <http:// www.ccarevista.ufc.br/seer/index.php/ccarevista/article/ view/3477/1030>. Accessed: Dec. 20, 2014

BARTZ, M.L.C. et al. Earthworm richness in land-use systems in Santa Catarina, Brazil. Applied Soil Ecology, v.83, p.59-70, 2014a. Available from: <http://www.sciencedirect.com/science/ article/pii/S092913931400078X\#>. Accessed: Feb.18, 2015. doi: 10.1016/j.apsoil.2014.03.003.

BARTZ, M.L.C. et al. The influence of land use systems on soil and surface litter fauna in the western region of Santa Catarina. Revista Ciência Agronômica (UFC. Online), v.45, p.880-887, 2014b. Available from: <http://ccarevista.ufc.br/seer/index.php/ ccarevista/article/view/3453/1050>. Accessed: Jan. 30,2015.

BARTZ, M.L.C. et al. Earthworms as soil quality indicators in Brazilian no-tillage systems. Applied Soil Ecology, v.69, p.39-48, 2013. Available from: <http://dx.doi.org/10.1016/j. apsoil.2013.01.011>. Accessed: Feb. 23, 2015. doi: 10.1016/j. apsoil.2013.01.011

BARTZ, M.L.C. et al. Minhocas Urobenus sp.: das matas para as áreas sob plantio direto. Revista Plantio Direto, v.124, p.6-7, 2011 Available from: <http://www.plantiodireto.com.br/?body=cont int\&id=1059>. Accessed: Mar. 20, 2015.

BROWN, G.G. et al. Earthworms stimulate plant production. In: BROWN, G.G.; FRAGOSO, F. (Orgs.). Minhocas na América Latina biodiversidade e ecologia. Londrina: Embrapa Soja, 2007. p.509-517.
COMPANHIA NACIONAL DE ABASTECIMENTO (CONAB). Custos de produção agrícola: a metodologia da Conab. Brasília: CONAB, 2010. Available from: <http://www.conab.gov.br/ conabweb/download/safra/custos.pdf>. Accessed: Jun. 17, 2013.

CORSINI, P.C.; FERRAUDO, A.S. Efeitos de sistemas de cultivo na densidade e macroporosidade do solo e no desenvolvimento radicular do milho em Latossolo Roxo. Pesquisa Agropecuária Brasileira, v.34, p.289-298, 1999. Available from: <http://www. alice.cnptia.embrapa.br/bitstream/doc/89568/1/pab35696.pdf>. Accessed: Nov. 24, 2014.

EPAGRI. Síntese anual da agricultura de Santa Catarina 2013-2014. Florianópolis, 2014a. Available from: $<$ http://docweb. epagri.sc.gov.br/website_cepa/publicacoes/Sintese_2014.pdf $>$. Accessed: Jun, 04, 2015.

EPAGRI. Custo de produção. Florianópolis, 2014b. Available from: <http://www.epagri.sc.gov.br/?page_id=2696>. Accessed: Sept. 03, 2014.

HOFFMANN, R. et al. Administração da empresa agrícola. São Paulo: Pioneira, 1987. 325p.

GREENLAND, D.J. Soil management and soil degradation. Journal of Soil Science, v.31, p.301-322, 1981. Available from: $<$ http://onlinelibrary.wiley.com/doi/10.1111/j.1365-2389.1981. tb01708.x/pdf>. Accessed: Mar. 25, 2015. doi: 10.1111/j.13652389.1981.tb01708.x/pdf.

LAZZAROTTO, J.J. et al. Viabilidade financeira e riscos associados à integração lavoura-pecuária no estado do Paraná. Organizações Rurais \& Agroindustriais, v.12, n.1, p.113$130,2010$.

MARCHÃO, R.L. et al. Qualidade física de um Latossolo Vermelho sob sistemas de integração lavoura-pecuária no Cerrado. Pesquisa Agropecuária Brasileira, v.42, p.873-882, 2007. Available from: $<$ http://www.scielo.br/pdf/pab/v42n6/v42n6a15.pdf>. Accessed: Feb. 12, 2015.

MARTHAJUNIOR, G.B. et al. Dimensão econômica de sistemas de integração lavoura-pecuária. Pesquisa Agropecuária Brasileira, v.46, n.10, p.1117-1126, 2011. Available from: <http://www.scielo. $\mathrm{br} / \mathrm{scielo} . \mathrm{php}$ ? pid $=\mathrm{S} 0100-204 \mathrm{X} 2011001000002 \& \mathrm{script}=\mathrm{sci}$ arttext $>$. Accessed: Oct. 10, 2014. doi: 10.1590/S0100204X2011001000002.

PEREIRA, J. de M. et al. Relationships between microbial activity and soil physical and chemical properties in native and reforested Araucaria angustifolia forests in the state of São Paulo, Brazil. Revista Brasileira de Ciência do Solo, v.37, n.3, p.572586, 2013. Available from: <http://dx.doi.org/10.1590/S010006832013000300003>. Accessed: Oct. 10, 2014. doi: 10.1590/ S0100-06832013000300003.

SILVA, R.F. et al. Análise conjunta de atributos físicos e biológicos do solo sob sistema de integração lavoura-pecuária. Pesquisa Agropecuária Brasileira, v.46, p.1277-1283, 2011. Available from: <http://www.scielo.br/pdf/pab/v46n10/46v10a22.pdf>. Accessed: Sept. 03, 2014.

SILVA, H.A. da et al. Viabilidade econômica da produção de novilhas leiteiras a pasto em sistema de integração lavoura-pecuária. Pesquisa Agropecuária Brasileira, v.47, n.6, p.745-753, 2012. Available from: <https://www. 
lume.ufrgs.br/bitstream/handle/10183/107190/000939882. pdf?sequence=1>. Accessed: Sept. 03, 2014.

SOLDATELLI, D. Margem bruta, lucro e outros índices. In: SEMANA DE ATUALIZAÇÃO EM ADMINSTRAÇÃO RURAL, 1991, Lages, SC. Anais... Florianópolis: SAA/EPAGRI, 1992. p.27-48.

SPERA, S.T. et al. Integração lavoura e pecuária e os atributos físicos de solo manejado sob sistema plantio direto. Revista Brasileira de Ciência do Solo, v.33, n.1, p.129-136, 2009. Available from: $<$ http://dx.doi.org/10.1590/S0100-06832009000100014>. Accessed: Nov. 11, 2014. doi: 10.1590/S0100-06832009000100014.

TEDESCO, M.J. et al. Análises de solo, plantas e outros materiais. Porto Alegre: Universidade Federal do Rio Grande do Sul, 1995. 174p. (Boletim Técnico, 5.).

TER BRAAK, C.J.F.; SMILAEUR, P. Reference manual and user's guide to CANOCO for Windows: software for canonical community ordination (version 4). Ithaca: Microcomputer Power, 1998. 500p.

VEIGA, M. et al. Atributos de solo e de plantas afetadas pelo manejo da pastagem anual de inverno em sistemas de integração lavoura-pecuária. Ciência Rural, v.42, p.444-450, 2012. Available from: <http://www.scielo.br/scielo.php?pid=S010384782012000300010\&script $=$ sci_arttext $>$. Accessed: Nov. 20, 2014. doi: 10.1590/S0103-84782012000300010.

VEIGA, M. Metodologia para coleta de amostras e análises físicas do Solo. Florianópolis: Epagri, 2011. 52p. (Boletim Técnico, 156).

VEIGA, M. et al. Tillage systems and nutrient sources affecting soil cover, temperature and moisture in a clayey oxisol under corn. Revista Brasileira de Ciência do Solo, v.34, p.2011-2020, 2010. Available from: <http://www.scielo.br/scielo.php?script=sci arttext\&pid=S0100-06832010000600025>. Accessed: Nov. 20,2014. doi: 10.1590/S0100-06832010000600025. 